\title{
Systemic Causes and Consequences of Spatially Mediated Depopulation ${ }^{1}$
}

\author{
V. N. Leksin* \\ Federal Research Center Informatics and Control, Russian Academy of Sciences, Moscow, 117312 Russia \\ *e-mail: leksinvn@yandex.ru \\ Received April 5, 2021; revised April 8, 2021; accepted July 16, 2021
}

\begin{abstract}
Depopulation processes in Russia-in almost all of its regions and settlements-are similar to those observed in almost all developed countries, and they additionally intensified in the post-Soviet period during the 30-year transformation of public relations in the country. The general and particular foundations of depopulation - of a mental, social, economic and political nature - are presented in studies by Russian geographers and demographers, sociologists and economists, ethnographers and political scientists. Summarizing and supplementing their results, the author proposes a verbal model of spatially mediated depopulation processes. It characterizes the logic of these processes in modern Russia and the dominance of economic factors in them. The article critically evaluates the methods of statistical accounting for spatially mediated depopulation. The controversial role of interregional and intraregional migration in the desertification of territories is shown.
\end{abstract}

Keywords: spatial heterogeneity, interregional migration, intraregional migration, desertification of territories

DOI: $10.1134 / \mathrm{S} 2079970521040109$

\section{FORMULATION OF THE PROBLEM}

Concern about the decrease in the country's population (depopulation) is increasingly encountered in speeches by Russian politicians, the media, state and regional strategic documents, national projects and programs, and periodically it becomes the subject of scientific discussions, etc. This concern is justified, reinforced by the latest news: the natural population decrease in Russia in 2020 more than doubled-to 688700 people versus 316200 people in 2019; the number of births in 2020 became the lowest since 2002 , and for the first time in 15 years, the total number of Russian residents decreased by almost $0.5 \mathrm{mln} .^{2}$ The outlook is also disappointing: the results of forecasts based on different methods and information concur that, while maintaining modern demographic trends, Russia by the middle of the 21 st century (i.e., in 30 years) may lose up to $15 \mathrm{mln}$ people (Demograficheskoe ..., 2009; Rybakovsky, 2012). Any evidence and consequences of depopulation in Russia continue to cause both a unanimously negative and often emo-

\footnotetext{
${ }^{1}$ This article is the first part of a study on spatially mediated depopulation processes in Russia, carried out by Professor V.N. Leksin in 2019-2020. The second part of the study will be published in a subsequent issue of Regional Research of Russia.

2 The natural population decrease in 2020 amounted to 688000 people (https://ria.ru/20210208/ubyl-1596552809.html); the number of children born in the Russian Federation in 2020 was the lowest since 2002 (https://www.interfax.ru/russia/749946).
}

tional attitude towards these facts, and attempts to interpret them from fundamentally different positions. At the same time, no one disagrees with the fact that the state and outlook of the situation largely depend on extremely significant and essentially different causes and effects of spatially mediated depopulation, i.e., depopulation in the space of specific territories: regions, municipalities, and individual cities and villages.

At the end of 20th and beginning of the 21st century, it became obvious that depopulation in developed countries results from accumulating changes in society's attitudes towards childbirth and increasingly less-traditional family values, coupled with a physiological reduction in the reproductive potential of the indigenous population (Vishnevsky 2005a, 2005b, 2012; Vishnevsky and Shcherbakova, 2018). It is no coincidence that in such countries, hopes for compensatory population functions owing to intercountry migration dominate, which are justified. The undisputed leader in terms of attracting migrants and in their positive impact on the demographic situation has been and remains the United States. In Russia, depopulation due to natural population decrease is spatially heterogeneous, and public opinion voices increasing concern about the desertification of specific territories as their inhabitants move to places attractive to them. The country relies on the effectiveness of the policy of economic incentivization towards childbearing and 
retention of family values, on health programs aimed at increasing life expectancy, and on the "return of compatriots" from the post-Soviet countries of the Russia's Near Abroad.

It should be noted that labor migrants from former Soviet countries today are becoming a common component of the Russian socioeconomic reality. They gravitate, like Russian interregional and intraregional migrants, mainly towards large cities and agglomerations. Labor migrants from former Soviet countries are becoming an increasingly important labor resource, and the reduction in their number is seen as a problem on a national scale. At a December 2020 meeting of the State Council and Council under the President of the Russian Federation for Strategic Development and National Projects, First Deputy Prime Minister A.R. Belousov said that the construction industry is experiencing a large shortage of personnel, since labor migrants are "cut off because of the pandemic." The head of Tatarstan, R.N. Minnikhanov, raised the issue of "a labor shortage at construction sites due to introduction of antiepidemiological restrictions." As a result, the list of instructions by the President of the Russian Federation following the results of this meeting on January 18, 2021, included a clause on "establishing a simplified procedure for attracting workers who are not citizens of the Russian Federation, including from certain CIS countries, to perform construction and installation work in compliance with sanitary and epidemiological requirements in order to prevent the spread of the new coronavirus infection COVID-19." ${ }^{3}$

The subject of this article is exclusively spatially mediated depopulation, which was and remains at the center of the scientific interests of Russian geographers, demographers, sociologists, economists, ethnographers, and statisticians, such as A.G. Vishnevsky, O.B. Glezer, V.V. Fauzer, Z.I. Kalugina, N.V. Mkrtchyan, T.G. Nefedova, L.L. Rybakovsky, and many others. The article makes no attempt to compete with their conclusions, but instead follows the path they have outlined, emphasizing those few aspects of spatial depopulation that the author today sees as the most controversial: what is primary and most important in the problem of spatially mediated Russian depopulation and what are the similarities between the phenomena of the "dying village" and extinction of urban settlements in different periods of our history. At the same time, the article does not consider the general causes and consequences of depopulation of the country and its regions in connection with natural decrease, since this is an issue that requires separate analysis.

\footnotetext{
${ }^{3}$ List of instructions following a joint meeting of the State Council and the Council for Strategic Development and National Projects. http//www.kremlin.ru/acts/assignments/orders/64900.
}

\section{STATISTICS AND THE MOST IMPORTANT ASPECTS OF A SPATIALLY MEDIATED DEPOPULATION}

Until recently, statistics have indicated a seemingly relatively acceptable situation. For 2015-2019, in the Russian Federation as a whole, the population even increased by $1.4 \%$ and remained stable during 2019. Yes, the mortality rate exceeded the birth rate, but this was to some extent offset by the increase in migration. However, there were serious corrections in 2020, which cannot be explained by epidemiological factors alone. Against this background, long-term stable phenomena of spatially mediated depopulation have become especially significant-a constant decrease in the number of inhabitants in vast territories of many regions and in thousands of settlements, which traditionally has been taken as an indicator of socioeconomic disadvantage. Statistics note these phenomena in most federal subjects, in particular, the Komi Republic, the Jewish Autonomous Oblast, and Magadan, Tambov, Kurgan, Oryol, Tver, Arkhangelsk, Penza, Ivanovo, Novgorod, and Pskov oblasts. According to Rosstat, over the past 3 years, in 24 other federal subjects, the population has been decreasing annually by more than $2 \%$. In 2019 , in 46 federal subjects, the migration outflow exceeded the number of arrivals from other regions, and in nine federal subjects (the republics of Kalmykia, Komi, North Ossetia-Alania; Zabaykaslky and Kamchatka krais; the Jewish Autonomous Oblast; and Arkhangelsk, Magadan, and Omsk oblasts), net migration rate was more than -5 per 1000 people.

Statistics are often criticized, and who has not heard the biting expression: "There are three kinds of lies: lies, damned lies, and statistics," which the witty Mark Twain, in Chapters from My Autobiography, attributed without any reason to Disraeli himself. This is just as untrue as what Russian scoffers said in the novel The Twelve Chairs: "Statistics know everything." The truth is that only statistics provides, without resorting to sociological polls (these are two fundamentally different fields of information), objective knowledge about what is happening in the world of economics, social life, ecology, and demography. It is also true that statistics, claiming to know everything, constantly renews its methods and expands the scope of its activity (recall, e.g., a relatively young direction of statistical research-the study of innovation).

Analyzing the possibilities of domestic statistics in creating an array of reliable information about the depopulation processes in territories of the world's largest state, one need hardly recall that they are mainly characterized by population parameters, the main source of information about which are infrequent all-Russian population censuses. To estimate the population size in the intercensal period, Rosstat should conduct separate calculations using data on births, deaths, arrivals, and departures, and changes in 
population as a result of constant administrative and territorial transformations. In this case, information about births and deaths should come daily from the Unified State Registry of Civil Status Acts, and information on each migrant should be collected from federal statistical observation questionnaires. The registration of natural population movement in Russia is well established, but obtaining information on people's migration remains problematic. Thus, Rosstat monthly processes about 300000 records of arrivals based on primary migration and registration records taken by personnel on paper forms, information from which is only then entered into territorial statistical offices in electronic form. Certain errors are inevitable here, but for a number of reasons, the transition to electronic data transmission will be possible only from January 2024.

I would like to note that accounting for migration flows in Russia is extremely important because, according to the report of the UN Economic and Social Council on migration in the world, ${ }^{4}$ in 2019 , $12 \mathrm{mln}$ migrants stayed on Russian territory. This is the fourth largest in the world; in the first place is the USA ( $18 \%$ of the total number of migrants on the planet); in second and third place, Germany and Saudi Arabia; fifth is the United Kingdom. Recall that it was precisely the underestimation of migration flows that caused the discrepancy between the results of the 2002 and 2010 population censuses and the current assessment of Russia's resident population (the difference was 1.8 and $1.0 \mathrm{mln}$ people, respectively).$^{5}$ Therefore, starting in 2011, the statistical record of longterm migration was supplemented with a list of those registered at the place of residence for a period of 9 months or more, as well as persons no longer registered at the place of residence due to expiration of the registration period. However, assessment of the spatial parameters of depopulation, namely, how population size in specific settlements changes, is much more influenced by the results of the intraregional and interregional, long-term and commuting labor migration of Russian citizens. Unfortunately, information on internal Russian migration differs significantly. According to the 2010 census, about $2.3 \mathrm{mln}$ people worked in regions other than where they live (without identification of commuting). A study of the situation based on commuting data at the level of settlements showed that about $11 \%$ of the working-age population of Russia is commuters, i.e., more than $7 \mathrm{mln}$ people (Antonov, 2016); in a number of publications, it was

\footnotetext{
${ }^{4}$ Report about migration in the world 2020. UN Economic and Social Council. https://publications.iom.int/system/files/ pdf/frnal-wmr_2020-ru.pdf.

5 The next all-Russian census is scheduled for 2021 with rapid publication of the results, and it has been repeatedly stated that the next one will be a fundamentally different, "digital" census.
}

assumed that there are many more such labor migrants (Makhrova et al., 2012; Makhrova et al., 2017).

Locally mediated depopulation is increasingly becoming a subject of special studies, and as an example, the author cites only a few of more than a hundred publications on this topic in leading Russian journals in the last 10 years. First of all, these are distinguished by the thoroughness and systemic nature of the work by Russian geographers on mobility of the Russian population based on the 2010 All-Russian census (Antonov, 2016), on the international and internal aspects of Russian labor migration (Mkrtchyan and Florinskaya, 2018), commuting in the largest agglomerations (Antonov, 2021; Makhrova and Kirillov, 2016; Makhrova et al., 2012; Makhrova et al., 2017; Shitova and Shitov, 2008), links between migration and the labor market (Florinskaya et al., 2015), the specifics of depopulation in rural areas (Nefedova, 2003, 2013, 2015), etc. An example of a detailed study of these issues in aggregate can be found in recent publications on Siberia and the Far East, which show the features of these regions in the country's spatial development strategy (Seliverstov, 2017), the specifics of secondary and ternary cities under conditions of demographic compression (Fomin and Bezverbnyy, 2018), migration flows in Siberian regions (Samarukha et al., 2018; Shevtsova, 2017; Shvorina and Faleychik, 2018), and an interesting comparison of demographic forecasts and statistics of the spatial development of Siberia and the Far East (Fomin, 2019), Moreover, all these studies confirm the typical depopulation phenomena noted above in these regions.

The author would like to draw readers' attention to a report presented at the Gaidar Forum-2020 by wellknown scientists who have long and fruitfully studied the internal migration phenomena (Mkrtchyan et al., 2020). This compact publication, based on current Rosstat statistics and surveys, data from the 2010 census, as well as materials from field studies by the authors, discusses the features of internal interregional migration associated with moving to a new place of residence and temporary work, taking into account the specifics of such migration flows to a number of regions, the impact of migration processes on the socioeconomic situation in different parts of the country, the characteristics of migration from small and medium-sized cities, as well as from regions of the North Caucasus. Of considerable interest are assessments by these authors on the possibilities of using the migration resource to overcome unfavorable demographic trends in regions. The authors note that according to the 2010 census, about $2.3 \mathrm{mln}$ people worked in regions other than where they live and that 
"the level of interregional migration is quite stable in today's Russia."6

The overall pattern of intraregional population movements (Beskov et al., 2018; Vishnevsky, 2005a, 2005b, 2012; Vishnevsky et al., 2007) is indeed quite stable, and the available statistics, processed datasets of relevant scientific publications and reports by local media, as well as the research results and observations of the author of this article, allow us to identify "the primary and the most important" as follows.

(1) For over 30 years, Russia's population has been migrating to large cities, their agglomerations, and economic activity centers of large corporations for reasons of a predominantly economic nature and due to the futility of finding decent employment at one's initial place of residence. This, somewhat decreasing the all-Russian level of poverty and unemployment, leads to depopulation in rural settlements and small and medium-sized towns and is becoming another factor in the demographic crisis and increased territorial differentiation.

(2) In fact, all (more than 95\%) interregional and intraregional migration is labor-related. It is either oriented towards relocation to and permanent residence at a new place of employement (usually in a large city), or, more often, it is long distance commuting (otkhodnichestvo or shift work) with a particular frequency of return to the place of permanent residence. These are fundamentally different processes, differing in motivation and impact on the socioeconomic situation in regions and municipalities. The most important incentive for the development of commuting in postSoviet Russia has been the high rate of motorization of the population and the presence of rail and bus connections with major cities. In the absence of local labor resources, so-called corporate shift camps have formed in areas of intensive economic activity far from large cities.

(3) In terms of its scale, labor commuting is comparable to moving to a permanent place of work and residence, and in a third of regions, it significantly exceeds them. The inflow of commuters partly increases consumer demand in their places of permanent residence (rural settlements, small and mediumsized cities), thereby stimulating development of a service infrastructure oriented towards local demand and preserving the situation of preference for earning money outside the initial place of residence.

(4) Despite all the problems related to migrants' acquisition of housing in the places the move to, the

\footnotetext{
${ }^{6}$ The report drew attention to the comparability of migration parameters in Russia with the corresponding indicators for Germany and Japan (in the USA, Great Britain, and Australia, these parameters are significantly higher), as well as to the fact that the scale of this migration in Russia is greater than in many countries of Southern and Eastern Europe, because the population there engages in international migration, primarily within the EU.
}

solution to these problems, due to the relatively better ratio of income and cost of housing in large cities and agglomerations, often happens earlier and more reliably than in places of previous residence, where, moreover, there are no employment prospects. This is evidenced by the correlation between the scale of migration inflow and volume of housing construction in large cities and agglomerations.

(5) Almost everyone who wanted to and could participate in interregional and intraregional migration has already done so, making it very problematic to realize hopes for any options for new development of now empty or desolate territories using the mechanisms of "Far Eastern hectare," "village doctor," etc., unless the interests of big business and, less often, the enthusiasm of individuals and their families are behind it.

This verbal model of the formation of spatially mediated depopulation in Russia reflects its logic both in its typical and seemingly most paradoxical manifestations. Refuting the conventional wisdom about the predominant depopulation of Siberian and Far Eastern regions, the author cites the latest data on the situation in the Sakha Republic (Yakutia), where, according to Rosstat, as of January 1, 2020, the population was 972000 people, of which the share of the urban population was $66 \%$, and rural, $34 \%$. Compared to 2015, the republic's population increased by $1.6 \%$, with an increase in its number in large cities over the same period by $2.9 \%$ and a decrease in rural areas by $0.9 \%$ (the general situation for Russia). The increase in the population of Yakutia is due to continuing natural increase, as well as a decrease in migration outflow. ${ }^{7}$ Despite the fact that the birth rate is decreasing throughout Russia, the number of newborns in the republic continues to increase: in 2010, 3748 children were born, and in 2018, 4638 (an increase of $27 \%$ ). The traditions of large families (three or more children) have been preserved and incentivized in every possible way, and the share of large families is one of the highest in the Far East. ${ }^{8}$ Let us not forget that about 40000 representatives of indigenous small-numbered peoples of the North living in Yakutia represent the most stable part of its population both in terms of population growth and nonparticipation in interregional migration.

The easiest way would be to explain the stability of Yakutia's population by the significant scale of support for social programs from the federal budget, but this

\footnotetext{
${ }^{7}$ At the end of the 1990s, about 30000 people left the republic annually; in the last three years, 3000-4000.

${ }^{8}$ In addition to payments of maternity allowances established at the federal level, additional maternity allowances have been allocated in Yakutia for the birth of a second child, and in 2018, the law On Large Family Status in the Sakha Republic (Yakutia) was adopted, which raised the age limit for large family status (and for obtaining various benefits) from 18 years for the eldest child to 23; the age of completion of studies at university; initial period of work; etc.
} 
support is associated only with interbudgetary relations and legalized compensation for extreme working and living conditions. It would be more feasible to point out the relatively favorable economic situation: in 2019, the growth of coal and oil production versus the previous year was $15 \%$; gas condensate, $11 \%$; gold, $21 \%$; silver, $\sim 10 \%$; GRP for the year increased by $3.5 \%$ (one of the highest in the country). And this has resulted not only from the work of natural resource industries or commissioning of the Power of Siberia gas pipeline. The volume of jobs and services of the nonresource sector and even the production of Yakutia's agricultural products (mainly meat and eggs) increased by almost $7.5 \%$.

The demographic situation and migration sentiments in Yakutia once again confirm the paramount importance of a simple condition for stabilizing positive trends in this area: if there are good jobs, there is little reason to leave. This, in particular, is the situation in the Yamalo-Nenets Autonomous Okrug-a long-term donor region to the federal budget, traditionally called the leader in GRP per capita. ${ }^{9}$ The natural and climatic conditions in the Yamalo-Nenets Autonomous Okrug are extremely unfavorable for the nonindigenous population, but the high (by Russian standards) wages, combined with social preferences provided by the richest Russian corporations, ensure increase of the resident population in the okrug: in 2015-2019, it increased by almost $2 \%$ due to natural increase and decrease in migration losses by almost ten times. At the same time, the employment structure is not that important. For example, in the urban settlement of Kharp in the Priuralsky district of the Yamalo-Nenets Autonomous Okrug, the unemployment rate is one of the lowest in Russia, and the population of 5000 has decreased by only 200 people in 3 years. A significant part of the working population works to serve the unique city-forming institutions of the Federal Penitentiary Service (one of them is the "Northern Owl" for life-sentenced prisoners), and at the railway station, ${ }^{10}$ chromite ore arriving from the nearby mine are constantly being loaded. The village has all the necessary social infrastructure facilities and itself looks quite comfortable.

It should be noted that the parameters of spatially mediated depopulation are significantly influenced by the ethnic factor. In Russia, the number of those who

\footnotetext{
9 The latter is not entirely correct, since the GRP of the YamaloNenets Autonomous Okrug is generated not only by its own able-bodied population, but also by a huge army of shift workers from many regions of the country. At the same time, it is noteworthy that this indicator is associated not only with the extraction of hydrocarbon raw materials; over the past 5 years, the production volumes of even agricultural products have increased (from RUB 2.1 to $2.7 \mathrm{bln}$ ).

${ }^{10}$ Moscow-Labytnangi and Labytnangi-Vorkuta passenger trains also stop here daily. Kharp is located near Salekhard Airport and the Labytnangi River port ( $\sim 50$ and $\sim 40 \mathrm{~km}$, respectively).
}

consider themselves Russians is decreasing the fastest (for the intercensal period of 1989-2010, by 7\%). They also have the lowest birth rate. This process, which the author previously called "national suicide" (2016), is also manifested by the fact that the number of residents in predominantly Russian rural and urban settlements is decreasing the most. One of the fundamental works (Nefedova, 2015), comparing rural life in different regions and districts of Russia, drew attention to the fact that this life is relatively more prosperous in rural settlements with a non-Russian population. Unfortunately, in multinational settlements, Russians have little inclination to adopt lifestyle habits of their non-Russian neighbors that lead to longevity, and this is a long-standing tradition. I.S. Aksakov (1988, p. 14), with the accuracy of an ethnographer, describes his impressions of the passage in January 1844 through Sarepta, where "they decided to stay in a hotel supported by the brotherhood.... ${ }^{11}$ What cleanliness and courtesy!... The streets are unusually clean; in front of each house there is a row of pyramidal poplars; the architecture is very special. I have seen respectable men of Sarepta with long German pipes. Russians are very fond of these kind Herrnhuters, respect them, marvel at their art and patience, but, nevertheless do not assimilate anything (author's italics). One has an unusually strange impression from this good-natured German republic in the wilderness of Russia!" Note however, that the birth rate among Russians in modern multinational villages is nevertheless somewhat higher than in predominantly Russian ones.

\section{THE "DYING VILLAGE" AND "DESERTIFICATION OF TERRITORIES" IN THE RUSSIA'S MOST RECENT HISTORY}

This section of the article may prove the most controversial, since the processes of "extinction" and "desertification" of territories (as well as their previous intensive settlement processes) are presented here as objectively conditioned and uncontested consequences of successive reconstructions of Russia's sociopolitical and socioeconomic life. A.N. Shvetsov and I wrote about this 20 years ago in the first volume of Municipal Russia, and in recent years I have repeatedly additionally argued these ideas in monographs and other publications about the causes of changes in the birth rate and the civilizational aspects of modern depopulation.

When discussing the situation with the "dying village," it should be remembered that the very concepts of "rural population" and "rural settlements" are not currently interpreted in the same way as they were about half a century ago. Then, in the conceptual dictionary of socioeconomic geography, based on the

\footnotetext{
${ }^{11}$ At the expense of the Moravian Brothers, or Herrnhuters, who moved to Russia.
} 
postulate of K. Marx on the separation of the city from the countryside as a result of separation of industrial and commercial labor from agricultural labor, it was argued that "in a rural settlement, the main sphere of employment is agricultural production" (Alaev, 1983). But already at that time, agricultural production was becoming more and more agroindustrial, and now the number of people employed exclusively in agriculture (even taking into account its strange composition in Rosstat) is by no means dominant. Is this why federal legislation tautologically defines a rural municipal settlement as "one or several rural settlements united by a common territory (settlements, villages, stanitsas, farms, kishlaks, auls, and other rural populated areas). $" 12$ The interpretation of this term in the state program on development of rural areas is no more intelligible. ${ }^{13}$

Historically, in Russia, the place of residence and place of work to meet the basic life needs of the population (for a long period of a predominantly agrarian, then peculiarly industrialized country) coincided for a long time. Domestic rural settlements were formed and over the centuries remained as points of concentration for those engaged exclusively in agricultural labor on large manor farms and associated land of peasant communities, as well as on the land holdings of free farmers, one-yard farmers, Cossacks and nonRussian peoples, in Siberia and in the Far East. In any case, all of these people were fed by agricultural labor at their place of residence, and it was almost never sufficient to form a mass prosperous stratum (the poverty of the Russian countryside was not an invention of fiction writers of that time). The very first changes in the social status of rural residents (the prereform and especially post-reform periods of the second half of the 19th century) led to the temporary (seasonal work) or permanent departure of part of the working-age population from villages, which to some extent compensated only for the still high birth rate in these settlements (Kaz'min, 2015).

During the Soviet period, the ideologically motivated rejection of small individual farms and orientation towards collective (collective-cooperative) and state (state-owned) farms with the creation of an extensive network of machine and tractor stations and development of marketing and consumer cooperation, mothballed the Russian village as a settlement whose inhabitants were occupied on one major farm (not counting, of course, employment on private home-

\footnotetext{
${ }^{12}$ Federal Law no. 131-FZ of October 6, 2003, On General Principles of Organization of Local Self-Governance in the Russian Federation (as amended on December 29, 2020). http:// www.consultant.ru/document/cons_doc_LAW_44571/.

${ }^{13}$ Resolution of Government of the Russian Federation no. 696 of May 31, 2019 On Approval of the State Program of the Russian Federation Comprehensive Development of Rural Areas and on Amendments to Some Acts of the Government of the Russian Federation (with amendments and additions as of October 17, 2019). http://www.consultant.ru/document/cons_doc_LAW_326085/.
}

steads). It should be noted that one of the problems of consolidating the rural settlement network, which began in the 1970s and continued in subsequent years, was to retain rural residents (in particular, young people), who, having gained freedom of movement, began to rapidly depart for urban settlements, where working conditions and life were much better than in the village. However, analysis of population movement trends in the Non-Chernozem zone showed that "most inhabitants of small rural settlements migrated beyond the borders their areas, bypassing central estates, i.e., the largest and most comfortable villages. Moreover, in ten regions of this zone, population decreased even in farm centers, and in six regions, population growth in the central estates of collective and state farms was ten times less than the outflow of rural population from the region as a whole. From Vladimir Oblast, 29 times more rural residents migrated than arrived at central estates; from Tula Oblast, 23; from Kalinin (now Tver) Oblast, 22; from Kostroma Oblast, 14; from Pskov Oblast, 12; from Novgorod Oblast, 10; etc.” (Strongina, 1984, p. 104). Note that this campaign, launched very actively, led both to the creation of large villages and to desolation of tens of thousands of "unpromising villages," but it was not completed. And one hardly needs to be reminded that at that time, the country's agriculture functioned throughout its entire territory under conditions of centrally planning, and the strict tasks for the production of agricultural products often did not take into account either its economically justified specialization or the natural and climatic conditions. Reliable evidence of this has been provided by F.A. Abramov and V.I. Belov, E.Ya. Dorosh, B.A. Mozhaev, and V.V. Ovechkin. The reduction in the number and population of rural settlements and even decrease in the area of cultivated agricultural land in Central Russia in the 1950s was influenced by the state-organized development of virgin and fallow lands-more productive, located, as a rule, to the south. Analysis of these processes and their driving forces in the 19th-20th centuries is convincingly presented in (Makhrova et al., 2012; Nefedova and Glezer, 2020).

With the transition of the Russian economy to competitive market relations and with the opening of free access to the country for relatively cheap agricultural products from all over the world, everything in domestic agriculture initially changed, except for the rural settlement network, but already in the results of the 2002 census, there were 13000 officially listed rural settlements without a single permanent resident; and in a number of Central Russian regions (Kostroma, Yaroslavl oblasts, etc.), such settlements constituted almost 20\%. Over 20 years (by June 2010), 23000 settlements disappeared from the map of the country, of which 20000 were rural settlements. In addition, almost 20000 (!) rural settlements still officially remaining as such no longer had a permanent population; their number in the intercensal period increased 
by almost $50 \%$. The decrease in the rural population became much larger than the decrease in the urban population, since in villages, apart from the phenomenally labor-intensive and virtually nonmarket homesteads, there is no work left-it has begun to concentrate in a few large agricultural holdings.

The reason for such changes in a significant part of Russia's territory one most often calls the noncompetitiveness of small-scale agricultural production in the context of its inherited material and technical backwardness and terminated existence of collective and state farms, despite the fact that the rural population of Non-Chernozem Russia itself inexactly disposed of land shares, was unable to unite into cooperatives, or achieve farm status. However, there is another, no less important reason: already in the first decade of the 21 st century, the productivity of agricultural labor even on large and medium-sized farms in Russia (like in the USSR), with rare exceptions, was several times lower than the productivity on the lands of their foreign competitors. However, if, whereas to maintain today's labor productivity, agriculture requires no more than $10 \mathrm{mln}$ people (1970 employment record), elementary technical modernization can halve this value. Agriculture in Russia, if it is commodity-market-oriented and competitive, has no other choice than to produce not only more cheaply, but also with fewer workers. This means that in the future, half the currently existing rural population has no other choice but to leave agriculture, and in many cases to leave rural settlements, which near cities are significantly becoming places of seasonal residence of townspeople and local otkhodniki.

All of the above is not merely the conclusion of the present author's research: studies on the problems of transformation of rural life in the last 30 years are evidence of the same, e.g., the excellently substantiated research of (Vishnevsky et al., 2007) on the demography of the modern village, the brilliant combination of statistics and sociology in monographs and articles by Novosibirsk scientists (Artemov and Novokhatskaya, 2006; Fadeeva, 2008; Kalugina and Fadeeva, 2009), the studies by Saratov scientist and his coauthors (Vinogradsky, 2009; Vinogradsky et al., 2013); books and articles by authoritative researchers of modern rural life (Koznova, 2000; Nefedova, 2003, 2013, 2015; Nefedova and Glezer, 2020), and publications on the results of such studies conducted in different regions of the country (Fomin, 2019; Fomin and Bezverbnyy, 2018; Samarukha et al., 2018; Seleznev et al., 2020; Seliverstov, 2017; Shevtsova, 2017; Ziyatdinova and Kuchaeva, 2008). In these studies (only a fraction of Russian publications on the topic of the Russian countryside known to the author), which have already dotted the i's in the genesis of the problems of modern rural reality, it is unreasonable not to take this into account in discussions about the "extinction" of the Russian countryside.
It is noteworthy that "dying village" is not a modern phrase: it is more than a hundred years old. At the beginning of the 20th century, it was the title of a book by A.I. Shingarev (1907), ${ }^{14}$ which illustrates the dubious prosperity of the "Russia Lost to Us," a fusion of meticulous zemstvo statistics and Shingarev's personal observations for the sanitary and economic state of two villages near Voronezh: Novozhivotinny (at the beginning of the 20th century, Novo-Zhivotinnoe) and Mokhovatki. Shingarev adequately solved the task set by the Voronezh District Sanitary Council. ${ }^{15} \mathrm{He}$ identified "the causes of high mortality and low population growth in the parish of the village of Novo-Zhivotinnoe" and cited the following reasons: "The low cultural level of the population and its terrifying material insecurity and landlessness are directly dependent on the social mistakes of the past and on the general modern conditions of Russian life" (Shingarev, 1907, pp. 7, 8). The root cause of "extinction of the village" was the dire lack of land, since after the "great reform," the peasants received a free, so-called "beggarly" allotment, surrounded on all sides by land of the landowners. Shingarev cites data that "for 395 audited souls in both villages, 320 dessiatins of the worst land were allocated for common use. ${ }^{16}$ Poor households-more than half the total-could not pay annual taxes of even three to four rubles, and in fact there was nothing to take from them. A quarter of the population had to buy bread year-round. Land scarcity forced the renting of land.... Approximately onethird of households had no means to rent and either had to leave their homes altogether and look for thirdparty earnings to support their existence, or die of hunger" (Shingarev, 1907, pp. 141, 142).

Almost half the adults went to the trades. Shingarev writes: "They worked as quarrymen, carpenters, bricklayers, stove-makers, shoemakers, etc. Work in the quarries, the most widespread local trade, was especially difficult. At the same time, the remuneration did not exceed 10-30 kopecks per day. There was also such a "divine trade" as "nursery." Peasant families took two-week- to four-month-old children from the orphanage of the provincial zemstvo for upbringing. For the upbringing of a foundling child, the zemstvo paid a peasant woman 20 rubles a year. Very often this "trade" turned into a kind of conveyor belt of death. Some families would bury child, go to the shelter after another.... In the village of Novo-Zhivotinnoye in $1884,12 \%$ of families were engaged in this type

\footnotetext{
${ }^{14}$ A.I. Shingarev was a graduate of Moscow University, a zemstvo doctor, and a prominent public figure, deputy of the second, third, and fourth State Duma and the Constituent Assembly, coauthor of the agrarian program of the cadets, minister of the first and second bodies of the Provisional Government. He was brutally murdered in early 1918.

${ }^{15}$ This work was first presented as a report to the Voronezh District Sanitary Council and Voronezh Department of the Russian Society for the Preservation of Public Health.

${ }^{16}$ Approximately 350 ha.
} 
of "trade;" in 1901, 33\%. Nevertheless, all trades taken together did not give the villagers a secure existence" (Shingarev, 1907, p. 181).

Against this background, Shingarev again emphasizes the sharp contrast between "the brilliant financial condition of the Russian Empire and the progressive ruin of the peasant masses of the disenfranchised and disadvantaged" (Shingarev, 1907, p. 197). However, the troubles of Novozhivotinny accompanied him for another 40 years: a monstrous fire in the prerevolutionary years and the actual destruction of all buildings during the battles during the Great Patriotic War. And it may seem all the more surprising that today this rural settlement not only has over 3200 permanent residents (according to the 2010 census, there were 2600 people); it is also one of three in Voronezh oblast where the population has grown even in the last year. There are no miracles to this. Immediately after the revolution, the main cause of "extinction"-landlessness-was eliminated. The peasants received 2860 ha of more fertile land confiscated from landowners, and today the territory exceeds 8500 ha. In Soviet times, the village was not deprived of agricultural technology, education, or medicine, and agricultural production yielded high profits. Today the village has a well-equipped kindergarten, hospital, school, post office, Sberbank branch, and even its own automated telephone exchange. Residents engage in agriculture, wholesale and retail trade, numerous social infrastructure facilities, and ten successful LLCs and CJSCs located on the territory of the settlement. There are conditions for work away from home: the village is located next to the Moscow-Voronezh highway, $27 \mathrm{~km}$ from the oblast center and $17 \mathrm{~km}$ from the district center. Let us not forget, though, that this is the chernozem Voronezh Oblast and there is good work there.

Rural Russia, shaped by centuries and recent decades, was doomed to change-both quantitative and qualitative. The rural way of life and the appearance of rural settlements generated by the huge internal market of the distant past, large collective (communal, collective, state farm) agriculture, life skills and habituation to a poorly supplied infrastructure, small needs, and equalizing poverty of the population, have been pushed to radical transformation by the consistent destruction of the former economic, household and social-motivational bases. Fundamental changes in the life of the Russian countryside are just beginning, and all of them will be associated with the formation of a new commodity-market environment in the Russian agricultural sector and the beginning of serious social stratification in the countryside, with realistically predictable changes in the rural settlement system.

Over the past 20 years of the creation of market capitalism preconditions, rural Russia has demonstrated all imaginable and inconceivable potential for survival. The villagers were the most prepared for any hardships in life. In contrast to many townspeople, they had not only the survival skills for any situation, but also their own production of the most necessary things. This potential is by no means exhausted, but it is useless (and motivationally harmful) for the phase of radical transformations of the agricultural and other economic bases of rural settlements. Now a different energy is required, which can neither be accumulated nor manifested in the former economic and quotidian guise, nor in the old form of rural Russia settlements. Changes are inevitable, but so far rural Russia is not ready for them, either materially or socially.

The Arctic Zone of the Russian Federation, stretching from northern Karelia to Chukotka, has become a total depopulation space in post-perestroika Russia, with dozens of "dying" or already "extinct" settlements, while simultaneously being a place of employment for hundreds of thousands of shift workers. This is another astounding example of a paradoxical and, at the same time logical, phenomenon, the essence of which was conceptually outlined at the beginning of the article. The global Arctic is generally characterized by instability of the resident population, which is primarily associated with the natural depletion of specific natural resources or a decrease in the need for specific infrastructural facilities (including those of a defense nature) that require the presence of just such a population. On the other hand, the growth of such a population often depends on short-term economic and foreign policy, and other situations. A $40 \%$ decrease in population in the Arctic Zone of North America at the beginning of the 20th century was caused by the decline of the Klondike gold rush. It was established (Smirnov, 2020) that the share of the Arctic in the world population peaked in the 1950s, after which it almost halved, while the population of the world Arctic increased from $1.3 \mathrm{mln}$ people in 1900; to $6.1 \mathrm{mln}$ in 1989; then decreased to $5.4 \mathrm{mln}$ by 2019 . The aggregate political, economic and social reasons associated with fundamental changes in post-Soviet Russia in the course of the 30 years (1989-2019) led to a decrease in the permanent population of the Russian Arctic by 1046000 people, or almost 30\% (Lytkina and Smirnov, 2019).

Most often, in characterizing the depopulation in the Russian Arctic, they mention the situation in Chukotka, where in the first 20 years after the 1989 census, the total population decreased threefold (with an increase in the number of indigenous peoples by $5 \%$ ), then stabilized by the present at about 50000 . In (Lek$\sin , 2018)$, this situation was demonstrated by a case study of the urban settlements of Pevek and Dikson (the former "capital of the Arctic"), which rapidly lost part of their population, as well as the now virtually nonexistent Chukotka villages of Iultin, Baranikha, Apapelgino (here, the city-forming airport proved unnecessary in market conditions), Valkumey, Gudym (a former military base), and Polyarny. However, this is not only a problem in Chukotka. 
A typical example of the emergence, growth, and, in our time, extinction of a settlement in the western part of the Russian Arctic is the village of Amderma, ${ }^{17}$ which at first (in the early 1980s) enjoyed a crowded and bustling life. Arising in the early 1930s near a center that extracted valuable fluorite, which became an urban-type settlement, then a regional center of a huge territory, Amderma, even after the reduction in fluorite production (1950s), did not lose its significance as a "gateway to the Arctic:" a multipurpose airfield with a modern runway, multistory buildings for military and social workers, a maritime trade port, a geological exploration expedition, a permafrost station, and a hydrometeorological center were built there. The air terminal received regular flights from Moscow and was a transfer point for flights to Dikson and Tiksi. The resident population at that time reached 70008000 people; according to the 1989 census, 5100. Currently, the population of Amderma is 530; i.e., it decreased by almost ten (!) times. The reasons are also typical: in the early 1990 s, the military presence relocated to Kotlas (since then, the high-rise buildings have been empty), then the permafrost station, the oil and gas exploration expedition, the construction department, and even the local hydrometeorological center were sequentially closed. Some hopes for return of the population to this once comfortable village are pinned solely on renovation of the Amderma airport, provided for in the Decree of the President of the Russian Federation of October 26, 2020, no. 645 On the Strategy for Development of the Arctic Zone of the Russian Federation and Ensuring National Security for the Period until 2035.

The issues of depopulation of Russia's Arctic territories are often discussed in the context of the all-Russian problem of the incessant depopulation of the country, but in the Russian Arctic, in connection with the uniqueness of its development "in the Soviet manner," and with the peculiarities of the modern stage of reassimilation of the Soviet-heritage infrastructure and defense facilities, they require a systematic understanding adequate to Arctic realities. Domestic researchers do a lot in this regard, studying the general parameters of demographic and migration processes in the Arctic (Demograficheskie ..., 2016); factors of Arctic migration (Shelomentsev et al., 2018), its intensity, directions, and results (Fauzer and Smirnov, 2020; Korovkin and Sinitsa, 2019); Arctic labor markets (Rzhanitsyna and Kravchenko, 2020); their typology by type of activity (Fauzer et al., 2019); and even theoretical and practical aspects of creating selfsufficient Arctic settlements (Buriy and Dmitrieva, 2015). In the last 5 years alone, dozens of publications have become known about the problems of the perma-

\footnotetext{
${ }^{17}$ The village of Amderma is located on the Yugorsky Peninsula on the Kara Sea east of the Yugorsky Shar Strait. The distance to the district center (Naryan-Mar) is $420 \mathrm{~km}$; to the railway station (Vorkuta), $270 \mathrm{~km}$.
}

nent Arctic population, and this alone more persistently forces us to answer the main question about its size, which will be adequate to the real need for workers in all spheres of employment (from drillers to scientists and chuma workers ${ }^{18}$ ). The correctness of the adopted strategies and programs for the development of the Arctic and each of its settlements depends on a scientifically substantiated answer to this question. So far, only the creators of shift camps are answering this question sensibly: however many workers will be required, this will be the population of the village.

It would be naive to believe that a sharp decrease in population in certain cities and towns and even cessation of their activities (ghost towns and abandoned villages) due to economic lack of demand or change in the role in the existing settlement system is a phenomenon characteristic only of former Soviet cities and towns. Let us be realistic: the existence of wellequipped settlements around the world will sooner or later cease if they were created exclusively to serve enterprises that exploit nonrenewable natural resources. Even during my youth spent at a Soviet institute, we were taught: if the mine closes, the village closes. However, this also applied to logging villages. The socioeconomic situation in many small Arctic settlements, which were created in Soviet times to meet national needs and lost a significant part of their potential and population with the onset of liberal market reforms, may seem similar to that faced by hundreds of so-called single-industry towns in Central Russia, Siberia, and the Far East. However, in reality, these are fundamentally different phenomena. Some of the population of such single-industry towns can nevertheless change the profile of their activities (at new enterprises, in the service economy, etc.) or use the mechanisms involved with commuting to work in nearby cities with diversified economic structure. Arctic settlements of the type described above have lost not the city-forming, but meaning-forming basis of their functioning. This creates a special socioeconomic situation with problems inherent to the entire population and each person individually.

\section{CONCLUSIONS}

The article attempts to comprehend the phenomenon of spatially mediated depopulation as a systemic result of the general demographic crisis, the point and uneven distribution of economic activity, sharp imbalance in places of employment and residence of the able-bodied population, expansion of the possibilities of spatial mobility, and discrepancy between the

\footnotetext{
${ }^{18}$ This profession consists in the arrangement and maintenance of temporary dwellings of nomadic reindeer herders, taking care of children and husband reindeer herder; it is a critical and laborintensive profession. In 2018, it was included in the official registry of professions in Russia, with the status of third-category reindeer breeder, with a salary of about RUB 15000 and a standard social package.
} 
inherited settlement system and its economic foundations. At the same time, paradoxically, the country's economic life today depends not on the consequences of depopulation, but only to some extent on the professional qualities of labor resources. In most settlements, however, there is not a situation of "no one to work", but there is a situation of "no job," and when employment opportunities arise where there are relatively well-paid jobs, this immediately becomes an incentive for the flow of the necessary labor force. Research and regulation of spatially mediated depopulation require objective information about these processes at the level of urban and rural settlements of any population size, and this determines the need for a fundamental change in the practice of statistical work in regions and municipalities.

\section{CONFLICT OF INTEREST}

The author declares no conflict of interest.

\section{REFERENCES}

Aksakov I.S. Pis'ma k rodnym. 1844-1849 (Letters to Family. 1844-1849), Moscow: Nauka, 1988.

Alaev, E.B., Sotsial'no-ekonomicheskaya geografiya: Ponyatiino-terminologicheskii slovar' (Socioeconomic Geography: Dictionary of Terms and Definitions), Moscow: Mysl', 1983.

Antonov, E.V., Labor markets of urban agglomerations in Russia, Reg. Res. Russ., 2021, vol. 11, no. 2, pp. 187-198.

Antonov, E.V., Labor mobility of the population of Russia according to the 2010 All-Russian census, Vestn. Mosk. Univ., Ser. 5: Geogr., 2016, no. 2, pp. 54-63.

Artemov, V.A. and Novokhatskaya, O.V., Rural life in 19702000: data for analysis, in Ekonomicheskoe razvitie Rossii (Economic Development of Russia), Novosibirsk: Inst. Ekon. Org. Prom. Proizvod., Sib. Otd., Ross. Akad. Nauk, 2006, pp. 205-233.

Beskov, S.K., Glezer, O.B., Gunko, M.S., Medvedev, A.A., and Savinykh, V.P., Analysis of the spatio-temporal dynamics of the habitability of territories by the example of Central Russia, Izv. Vyssh. Uchebn. Zaved., Geod. Aerofotos'emka, 2018, vol. 62, no. 1, pp. 96-105.

Buryi, O.V. and Dmitrieva, T.E., Theory and practice of creation of self-sufficient Arctic settlements, Izv. Komi Nauchn. Tsentra, Ural. Otd., Ross. Akad. Nauk, 2015, no. 3, pp. 141-148.

Demograficheskoe razvitie Rossii v XXI veke (Demographic Development of Russia in 21 Century), Osipov, G.V. and Rybakovskii, L.L., Eds., Moscow: Inst. Sots.-Polit. Issled., Ross. Akad. Nauk, 2009.

Demograficheskie i migratsionnye protsessy na Rossiiskom Severe: 1980-2000gg. (Demographic and Migration Processes in Russian North: 1980-2000), Fauzer, V.V., Ed., Syktyvkar: Syktyvkar. Gos. Univ. im. P. Sorokina, 2016.

Fadeeva, O.P., Social capital of Siberian village, in Rossiya $i$ rossiyane $v$ novom stoletii: vyzovy vremeni $i$ gorizonty razvitiya (Russia and Russians in the New Century:
Challenges of Time and Horizons of Development), Zaslavskaya, T.I., Kalugina, Z.I., and Bessonova, O.E., Eds., Novosibirsk: Sib. Otd., Ross. Akad. Nauk, 2008, pp. 511-533.

Fauzer, V.V. and Smirnov, A.V., Migration of the population in the Russian Arctic: models, routes, and results, Arkt.: Ekol. Ekon., 2020, no. 4 (40), pp. 4-18.

Fauzer, V.V., Smirnov, A.V., Lytkina, T.S., and Fauzer, G.N., Local labor markets in the Russian Arctic: classification by type of activity, Arkt.: Ekol. Ekon., 2019, no. 2 (34), pp. 4-17.

Florinskaya, Yu.F., Mkrtchyan, N.V., Maleva, T.M., and Kirillova, M.K., Migratsiya i rynok truda (Migration and Labor Market), Moscow: Delo, 2015.

Fomin, M.V., Demographic forecasts and the correctness of statistics of the spatial development of Siberia and the Russian Far East, Narodonaselenie, 2019, vol. 22, no. 3, pp. 15-29.

Fomin, M.V. and Bezverbnyi, V.A., Spatial framework of Siberia and the Russian Far East in conditions of demographic shrinkage: "second" and "third" cities, Nauchn. Obozr., Ser. 2: Gumanit. Nauki, 2018, no. 6, pp. 33-53.

Kalugina, Z.I. and Fadeeva, O.P., Rossiiskaya derevnya $v$ labirinte reform: sotsiologicheskie zarisovki (Reforms and Russian Village: Sociological Studies), Novosibirsk: Inst. Ekon. Org. Prom. Proizvod., Sib. Otd., Ross. Akad. Nauk, 2009.

Kaz'min, M.A., Zemel'nye reformy $v$ Rossii $X I X-X X$ vv.: Uroki proidennogo puti (Russian Land Reforms in 19th20th Centuries: Lessons of Past), Moscow: URSS, 2015.

Korovkin, A.G. and Sinitsa, A.L., Assessment of the intensity and directions of population movement in the regions of the Russian Arctic in 1991-2015, Nauchn. Tr. Inst. Narodokhoz. Progrnoz., Ross. Akad. Nauk, 2019, vol. 17, pp. 323-340.

Koznova, I.E., $X X$ vek $v$ sotsial'noi pamyati rossiiskogo krest'yanstva (20th Century in the Social Memory of the Russian Peasantry), Moscow: Inst. Filos., Ross. Akad. Nauk, 2000.

Leksin, V.N., Sud'by tsivilizatsii i russkii vopros: opyt sistemnoi dialektiki (The Fate of Civilizations and the Russian Question: The Experience of Systemic Dialectics), Moscow: Lenand, 2016, pp. 311-324.

Leksin, V.N., Socioeconomic problems of the Arctic: between the past and future, Ross. Ekon. Zh., 2018, no. 5, pp. 3-25.

Lytkina, T.S. and Smirnov, A.V., The Russian North in the conditions of global neoliberal politics: overcoming of spatial inequality or displacement? Mir Ross., 2019, vol. 28, no. 3, pp. 27-47.

Makhrova, A.G. and Kirillov, P.L., Seasonal pulsation of settlement pattern in the Moscow agglomeration under the influence of dacha and work commuting: approaches to studies and assessment, Reg. Res. Russ., 2016, vol. 6, no. 1, pp. 1-8.

Makhrova, A.G., Kirillov, P.L., and Bochkarev, A.N., Work commuting of the population in the Moscow agglomeration: estimating commuting flows using mobile operator data, Reg. Res. Russ., 2017, vol. 7, no. 1, pp. 36-44. 
Makhrova, A.G., Nefedova, T.G., and Treivish, A.I., Moscow agglomeration and "New Moscow," Pro Contra, 2012, no. 6 (57), pp. 20-33.

Mkrtchyan, N.V. and Florinskaya, Yu.F., Labor migration in Russia: national and internal aspects, Zh. Nov. Ekon. Assots., 2018, no. 1 (37), pp. 186-193.

Mkrtchyan, N.V., Florinskaya, Yu.F., and Kazenin, K.I., Vnutrennyaya migratsiya kak resurs razvitiya Rossii: Sotsial'no-ekonomicheskie effekty, izderzhki i ogranicheniya (Internal Migration as a Resource for the Development of Russia: Socioeconomic Effects, Costs, and Restrictions), Moscow: Delo, 2020.

Nefedova, T.G., Sel'skaya Rossiya na pereput'e. Geograficheskie ocherki (Rural Russia on a Crossroad: Geographical Essays), Moscow: Novoe Izd., 2003.

Nefedova, T.G., Desyat' aktual'nykh voprosov o sel'skoi Rossii: otvety geografa (Ten Topical Issues about Rural Russia: A Geographer's Viewpoint), Moscow: Lenand, 2013.

Nefedova, T.G., Migration mobility of population and otkhodnichestvo in modern Russia, Reg. Res. Russ., 2015, vol. 5, no. 3, pp. 243-256.

Nefedova, T.G. and Glezer, O.B., Transformation of the sociogeographical space of Russia, in Vyzovy i politika prostranstvennogo razvitiya Rossi $v$ XXI veke (Challenges and Policy of Spatial Development of Russia in the 21st Century), Moscow: KMK, 2020, pp. 214-251.

Rybakovsky, L.L., Demographic challenges: what awaits Russia? SOTsIS, 2012, no. 8, pp. 49-60.

Rzhanitsyna, L. and Kravchenko, E., The modern labor market in the Arctic zone of Russian Federation, Federalizm, 2020, vol. 25, no. 3 (99), pp. 39-51.

Samarukha, V.I., Krasnova, T.G., and Plotnikova, T.N., Migration of the population in the regions of Siberia, Izv. Baikal. Gos. Univ., 2018, vol. 28, no. 1, pp. 56-62.

Seleznev, I.A., Mikryukov, N.Yu., and Miryazov, T.R., Sociological analysis of the spatial development (by the example of the regions of Western and Eastern Siberia), Nauchn. Obozr., Ser. 2: Gumanit. Nauki, 2020, no. 6, pp. 5-23.

Seliverstov, V.E., Role of Siberia in the strategy of spatial development of Russia, Vopr. Nov. Ekon., 2017, no. 3 (43), pp. 27-37.

Shelomentsev, A.G., Voronina, L.V., Smirennikova, E.V., and Ukhanova, A.V., Migration factors in the Arctic zone of Russian Federation, Ars Admin., 2018, vol. 10, no. 3, pp. 396-418.

Shevtsova, E.V., Population migration trends and migration policy in Novosibirsk oblast, Izv. Irkutsk. Gos. Univ., Ser.: Politol., Religioved., 2017, vol. 20, pp. 91-101.
Shingarev, A.I., Vymirayushchaya derevnya: Opyt sanitarnoekonomicheskogo issledovaniya dvukh selenii Voronezhskogo uezda (An Endangered Village: The Experience of a Sanitary and Economic Research of Two Villages of the Voronezh District), St. Petersburg: Obshchestvennaya Pol'za, 1907, 2nd ed.

Shitova, Yu.Yu. and Shitov, Yu.A., Analysis and forecasting of commuting labor migration in Moscow region (by the example of Dubna town), Probl. Prognoz., 2008, no. 4, pp. 112-122.

Shvorina, K.V. and Faleychik, L.M., The general trends in the migration mobility of the population of the regions of the Siberian and Far Eastern Federal districts, Ekon. Reg., 2018, vol. 14, no. 2, pp. 485-501.

Smirnov, A.V., Population of the Global Arctic: dynamics, population, and resettlement centers, Arkt. Sever., 2020, no. 40, pp. 270-290.

Strongina, M.L., Improvement of rural settlement pattern, in Regional'nye problemy rasseleniya (Regional Problems of Settlement Pattern), Moscow: Sov. Izuch. Proizvod. Sil, 1984, pp. 103-105.

Vinogradsky, V.G., Orudiya slabykh: tekhnologiya i sotsial'naya logika povsednevnogo krest'yanskogo sushchestvovaniya (Tools of the Weak: Technology and Social Logic of Daily Peasant Life), Saratov: Saratov. Fil., Ross. Gos. Torgovo-Ekon. Univ., 2009.

Vinogradsky, V.G., Vinogradskaya, O.Ya., Nikulin, A.M., and Fadeeva, O.P., Krest'yanskie zhiznennye praktiki. 1991-2012 (Peasant Life Practices: 1991-2012), Saratov: Saratov. Fil., Ross. Gos. Torgovo-Ekon. Univ., 2013.

Vishnevsky, A.G., Izbrannye demograficheskie trudy. Tom 1. Demograficheskaya teoriya i demograficheskaya istoriya (Selected Demographic Studies, Vol. 1: Demographic Theory and Demographic History), Moscow: Nauka, 2005a.

Vishnevsky, A.G., Izbrannye demograficheskie trudy. Tom 2. Ekonomicheskaya demografiya. Analiz demograficheskikh protsessov (Selected Demographic Studies, Vol. 2: Economic Demography. Analysis of Demographic Processes), Moscow: Nauka, 2005b.

Vishnevsky, A.G., Demographic results of two decades in Russia, Mir Ross.: Sotsiol., Etnol., 2012, no. 3, pp. 3-40.

Vishnevsky, A.G. and Shcherbakova, E.M., Demographic brakes of economics, Vopr. Ekon., 2018, no. 6, pp. 48-70.

Vishnevsky, A.G., Kvasha, E.A., Khar'kova, T.L., and Shcherbakova, E.M., Russian village in the demographic dimension, Mir Ross., 2007, no. 1, pp. 17-58.

Ziyatdinova, F.G. and Kuchaeva, E.I., Rossiiskoe selo v rynochnykh usloviyakh (Russian Village in Market Conditions), Moscow: Yuniti-Dana, 2008. 